\title{
Changes in organ and body weight, serum amylase and antidiabetic effects of tannins from Spondias mombin on streptozotocin-induced diabetic rats
}

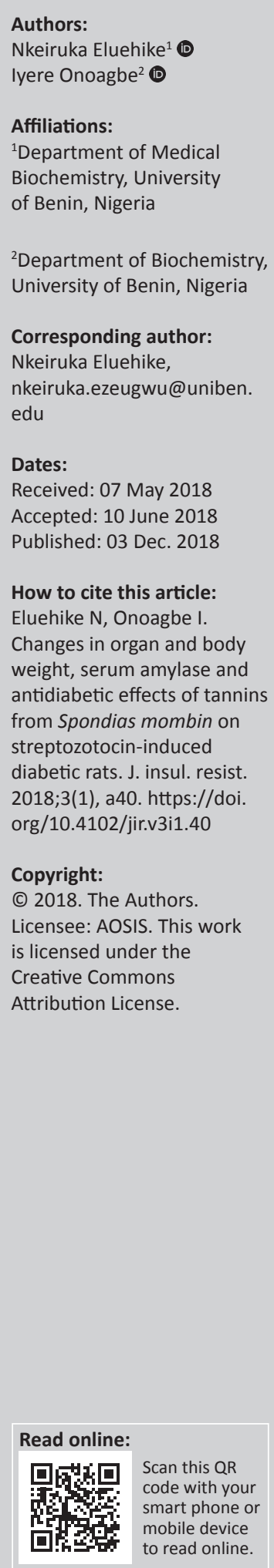

Background: Medicinal plants have been used for centuries in the management of chronic diseases including diabetes.

Aim: The purpose of this study is to evaluate the possible antidiabetic effects and changes in serum amylase activities, body weight and organ weight of tannins from Spondias mombin on streptozotocin-induced diabetic rats.

Setting: The study was conducted in the department of Biochemistry, University of Benin, Edo state, Nigeria.

Methods: A total of 24 albino Wistar rats were divided into four groups (A through D). Group A served as the normal control. Diabetes was induced in rats of groups B, C and D by singledose intraperitoneal administration of streptozotocin $(65 \mathrm{mg} / \mathrm{kg}$ body weight $)$ to overnightfasted rats. Only rats with fasting blood glucose $\geq 250 \mathrm{mg} / \mathrm{dL}$ were used for this study. Isolated tannins (100 mg/ $/ \mathrm{kg}$ body weight) were administered to rats of group D only. Blood glucose was monitored on Day 0, Day 3, Day 10 and Day 21. After 21 days experimental period blood samples were collected and used for serum amylase activities. Tissues (liver, pancreas, heart and kidney) were excised out and weighed.

Results: Tannins-treated rats showed a significant increase in body weight and serum amylase activity when compared with the diabetic control. Also, a significant decrease in blood glucose level was seen in the tannins-treated rats when compared with the diabetic control. A significant decrease in the weight of the pancreas and a significant increase in the weight of the liver were seen in the diabetic control rats when compared with the tannins-treated groups.

Conclusion: Tannins of Spondias mombin have an antidiabetic effect and can restore serum amylase and body weight changes resulting from streptozotocin induction.

\section{Introduction}

Diabetes is a disease of the pancreas characterised by multiple defects in its pathophysiology ${ }^{1}$ and abnormalities in protein, fat and carbohydrate metabolism. ${ }^{2,3}$ It is evident that this disease leads to hyperglycaemia and to many other complications such as hyperlipidaemia, hypertension, atherosclerosis, retinopathy, neuropathy and nephropathy. ${ }^{4}$ The World Health Organization (WHO) projects that diabetes will be the seventh leading cause of death in 2030. ${ }^{5}$ Statistics also show the disease will affect more than the current 347 million people with diabetes by $2030.6,7$ The Diabetes Association of Nigeria had put the diabetic population in Nigeria at about 10 million as of $2004 .^{8}$ The high cost of diabetic medications, their unavailability in poor developing countries and the high cost, where the majority of people in developing countries can barely afford such costs, coupled with the side effects from these drugs, have led to a search for a number of plants used to manage diabetic patients with folk medicines, and the innovation will result in isolating plant active secondary metabolites that can be cost-effective and safer than synthetic products.

Though the mechanism of these plants is not well documented, the majority of studies are being conducted to uncover the mechanism of action of these plants and their isolates. Hence, more attention is being paid to study the proper mechanism of these plants' actions along with the bioactive compounds responsible for these activities.

Tannins, a secondary metabolite from plants, have been described as developing glucose uptake through mediators of the insulin-signalling pathways, such as phosphoinositide 3-kinase and p38 mitogen-activated protein kinase activation, GLUT-4 translocation ${ }^{9,10,11}$ and antihyperglycaemic 
agent in diabetic rats. ${ }^{12}$ Iweala et al. ${ }^{13}$ have shown that the seeds of Spondias mombin possess hypoglycaemic effects in alloxan-induced diabetic rats, while Nkanu et al. ${ }^{14}$ have shown that the leaves of $S$. mombin produce hypoglycaemic and hypolipidemic effects in alloxan-induced diabetic rats. However, little or no work is available on the effect of the tannin extract of $S$. mombin leaves on streptozotocin-induced diabetic rats. The present study seeks to evaluate the serum amylase activity and changes in organ and body weight of diabetic rats treated with tannin extract from S. mombin leaves.

\section{Materials and methods Isolation of tannins}

The leaves of S. mombin were collected from a field around the University of Benin campus, Benin City, Nigeria. The leaves were authenticated by a botanist in the department of Department of Plant Biology and Biotechnology of the University of Benin, Benin City, Nigeria. A herbarium specimen was deposited at the University of Benin Herbarium with herbarium number $\mathrm{UBH}_{\mathrm{S}}$ 345. It was air dried and pulverised. The ground leaves (500 g) were weighed into sealable glass flasks and $4 \mathrm{~L}$ of $80 \%$ acetone $(\mathrm{v} / \mathrm{v})$ was poured in. ${ }^{15}$ The flasks were placed in a water bath at $70^{\circ} \mathrm{C}$ and shaken for $15 \mathrm{~min}$. After cooling, the supernatant was decanted and the extraction was repeated twice more. The supernatants were combined, the acetone was evaporated using a rotary evaporator at $40^{\circ} \mathrm{C}$ and the aqueous residue was lyophilised.

The crude tannin extract $(2 \mathrm{~g})$, dissolved in $100 \mathrm{~mL}$ of ethanol, was applied on a column $(5 \mathrm{~cm} \times 40 \mathrm{~cm})$ packed with Sephadex LH-20 gel (Sigma Aldrich, Darmstadt, Germany). Ethanol (1 L), used as the first eluent, allowed removal of low molecular weight phenolic compounds. Then $800 \mathrm{~mL}$ of $70 \%$ acetone $(\mathrm{v} / \mathrm{v})$ was used to elute tannins. Collected fractions from the stepwise gradient were tested for the presence of tannins by adding $0.1 \% \mathrm{FeCl}_{3}$ and monitoring for brownish green or blue-black coloration. Fractions that gave a positive test for tannins were bulked together. Solvent in the tannin fractions was removed using a rotary evaporator. The tannin extract was then stored in the freezer until used.

\section{Test animals}

A total of 24 male albino Wistar rats weighing $190 \mathrm{~g}-220 \mathrm{~g}$ were bought and kept in galvanised cages in the Department of Biochemistry animal house. They were divided into four groups containing six rats each. They were allowed access to feed and water ad libitum on a 12-hr light -12-hr dark cycle. The animals were acclimatised for 2 weeks before induction of diabetes.

- Group A served as the normal control and was given standard feed only.

- Group B were the experimentally induced diabetic rats without tannins extract treatment (diabetic control).

- Group C were the experimentally induced diabetic rats treated with the standard drug glibenclamide $5 \mathrm{mg} / \mathrm{kg}$ body weight (positive control).

- Group D were the experimentally induced diabetic rats and treated with $100 \mathrm{mg} / \mathrm{kg}$ body weight of tannins extract.
- Tannins extract was administered to the tannin-treated rats daily for 21 days using orogastric cannula.

\section{Induction of diabetes}

To overnight-fasted rats, streptozotocin (STZ) was dissolved in cold citrate buffer $(0.1 \mathrm{M}, \mathrm{pH} 4.5)$ and was administered intraperitoneally at a dose of $65 \mathrm{mg} / \mathrm{kg}$ body weight. Blood glucose level was measured on Day 0 and on the third Day after STZ induction using an Accu-Chek ${ }^{\circledR}$ Active Blood Glucose Meter (Roche Diagnostics, Mannheim, Germany); only rats with fasting blood glucose (FBG) level greater than $250 \mathrm{mg} / \mathrm{dL}$ (FBG $\geq 250 \mathrm{mg} / \mathrm{dL}$ ) were selected and used for the study. Thereafter blood glucose was monitored on Day 10 and Day 21 before sacrifice.

\section{Blood parameters}

Blood was collected from the tail on days $0,3,10$ and 21 from the control and experimental rats for FBG assay. At the end of the 21-Day experimental period the animals were fasted overnight and blood samples were collected and allowed to clot for $30 \mathrm{~min}$, after which they were centrifuged at $3000 \mathrm{rpm}$ for $15 \mathrm{~min}$. The serum was collected separately and used for serum amylase assay. Serum amylase activity was measured by the method of Wallenfels et al. ${ }^{16}$ as described in the manual of the TECO diagnostic $\alpha$-amylase kit.

Tissues (liver, pancreas, kidney and heart) were also excised and were homogenised in ice-cold normal saline $(1: 4 \mathrm{w} / \mathrm{v})$, centrifuged at $1000 \mathrm{~g}$ for $15 \mathrm{~min}$ and the supernatant stored in the freezer until analysis.

\section{Statistical analysis}

Data for all groups were expressed as mean \pm standard error of mean. Statistical analyses were performed using one-way analysis of variance and Student's $t$-test. Differences were considered to be statistically significant when the $p$-value was less than 0.05 using SPSS statistical package.

\section{Ethical considerations}

Treatment of the animals was in accordance with the principle of laboratory animal care (NIH publication 85-93, revised 1985).

\section{Results and discussion}

Table 1 shows the effect of tannins on the body weight of the rats. A significant decrease in body weight was seen in

TABLE 1: Effects of tannins on body weight of control and diabetic rats.

\begin{tabular}{lcccc}
\hline Groups & Day 0 & $\begin{array}{c}\text { Week 1 (after STZ } \\
\text { administration) }\end{array}$ & Week 2 & Week 3 \\
\hline A (normal control) & $190.0 \pm 5.7$ & $206.67 \pm 8.82^{\mathrm{a}}$ & $220.0 \pm 11.56^{\mathrm{a}}$ & $230.0 \pm 5.77^{\mathrm{b}}$ \\
$\mathrm{B}$ (diabetic control) & $210.0 \pm 10.0$ & $162.0 \pm 2.00^{\mathrm{b}}$ & $170.0 \pm 0.01^{\mathrm{b}}$ & $165.0 \pm 5.00^{\mathrm{b}}$ \\
$\mathrm{C}$ (positive control) & $210.0 \pm 2.14$ & $164.0 \pm 2.05^{\mathrm{b}}$ & $198.5 \pm 0.05^{\mathrm{a}}$ & $202.0 \pm 6.00^{\mathrm{a}}$ \\
D (tannin-treated) & $197.5 \pm 8.54$ & $167.8 \pm 7.94^{\mathrm{b}}$ & $185.5 \pm 11.41$ & $201.5 \pm 2.50^{\mathrm{a}}$ \\
\hline
\end{tabular}

STZ, streptozotocin

a, Statistically significant difference when compared with the diabetic control.

b, Statistically significant difference when compared with the normal control. 
TABLE 2: Effects of tannins on organ weight (grams) of control and diabetic rats.

\begin{tabular}{lcccc}
\hline Groups & Liver & Heart & Kidney & Pancreas \\
\hline A (normal control) & $6.87 \pm 0.36^{\mathrm{a}}$ & $0.78 \pm 0.01$ & $1.56 \pm 0.09$ & $0.61 \pm 0.04^{\mathrm{a}}$ \\
$\mathrm{B}$ (diabetic control) & $9.33 \pm 0.02^{\mathrm{b}}$ & $0.65 \pm 0.03$ & $1.58 \pm 0.02$ & $0.35 \pm 0.05^{\mathrm{b}}$ \\
C (positive control) & $7.01 \pm 0.12$ & $0.78 \pm 0.08$ & $1.48 \pm 0.05$ & $0.58 \pm 0.01^{\mathrm{a}}$ \\
D (tannin-treated) & $6.29 \pm 0.44^{\mathrm{a}}$ & $0.69 \pm 0.03$ & $1.45 \pm 0.13$ & $0.58 \pm 0.02^{\mathrm{a}}$ \\
\hline
\end{tabular}

aStatistically significant difference when compared with the diabetic control.

bStatistically significant difference when compared with the normal control.

TABLE 3: Effects of tannins on blood glucose levels $(\mathrm{mg} / \mathrm{dL})$ of diabetic treated and control rats.

\begin{tabular}{lcccc}
\hline Groups & Day 0 & $\begin{array}{c}\text { Day 3 (after STZ } \\
\text { administration) }\end{array}$ & Day 10 & Day 21 \\
\hline A (normal control) & $88.0 \pm 1.83$ & $89.2 \pm 2.54^{\mathrm{a}}$ & $94.25 \pm 2.96^{\mathrm{a}}$ & $93.3 \pm 1.37^{\mathrm{a}}$ \\
B (diabetic control) & $87.0 \pm 2.08$ & $328.3 \pm 11.50^{\mathrm{b}}$ & $365.3 \pm 9.39^{\mathrm{b}}$ & $363.5 \pm 8.17^{\mathrm{b}}$ \\
C (positive control) & $92.3 \pm 5.12$ & $328.4 \pm 6.70^{\mathrm{b}}$ & $262.0 \pm 7.79^{\mathrm{a}, \mathrm{b}}$ & $145.5 \pm 6.44^{\mathrm{a}, \mathrm{b}}$ \\
$\begin{array}{l}\text { D (tannin-treated } \\
\text { diabetic rats) }\end{array}$ & $93.0 \pm 4.52$ & $337.0 \pm 6.25^{\mathrm{b}}$ & $298.8 \pm 9.52^{\mathrm{a}, \mathrm{b}}$ & $179.0 \pm 9.68^{\mathrm{a}, \mathrm{b}}$ \\
\hline
\end{tabular}

STZ, streptozotocin

${ }^{a}$ Statistically significant difference when compared with the diabetic control.

bStatistically significant difference when compared with the normal control.

TABLE 4: Effects of tannins on serum amylase level of control and diabetic rats

\begin{tabular}{lc}
\hline Groups & Serum amylase (IU/L) \\
\hline A (normal control) & $36.27 \pm 1.37^{\mathrm{a}}$ \\
B (diabetic control) & $8.90 \pm 1.06^{\mathrm{b}}$ \\
C (positive control) & $40.61 \pm 1.38^{\mathrm{a}}$ \\
D (tannin-treated diabetic rats) & $25.88 \pm 1.14^{\mathrm{a} \cdot \mathrm{b}}$ \\
\hline
\end{tabular}

IU/L, international units per litre.

astatistically significant difference when compared with the diabetic control.

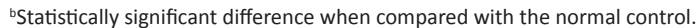

the diabetic control group, which continued throughout the experimental period. On the other hand, administration of tannin extract to the diabetic rats led to a significant $(p<0.05)$ increase in body weight at Week 3. For the glibenclamide-treated group, significant increase was seen at Weeks 2 and 3.

Table 2 shows the organ weights of rats treated with tannin extract for 3 weeks. A significant $(p<0.05)$ increase and a significant $(p<0.05)$ decrease in the weights of the liver and pancreas, respectively, were observed in the diabetic control rats when compared to the normal control. Administration of tannin extracts reverts these changes seen in the diabetic control groups, whereas non-significant changes $(p>0.05)$ were seen for the hearts and kidneys of all STZ-induced rats when compared with the control.

Table 3 shows the effects of tannins on blood glucose level of control and tannins-treated diabetic rats.

A significant increase $(p<0.05)$ in blood glucose level was seen in the diabetic rats at Day 3 after STZ administration when compared with the normal control. Administration of tannin extracts led to a significant $(p<0.05)$ decrease in blood glucose level at Day 10 and Day 21 when compared with the diabetic control groups but was not significantly reduced when compared with the normal control.

Table 4 shows the effects of tannins on serum amylase level of control and diabetic rats.
The serum amylase results showed a significant decrease in serum amylase activity in the diabetic control rats. A significant increase in serum amylase activity was seen in the tannin-treated diabetic rats when compared with the diabetic control groups.

\section{Discussion}

Diabetes is the leading cause of mortality worldwide and STZ, which is a naturally occurring nitrosourea, has been widely used to induce insulin-dependent diabetes mellitus in experimental animals because of its toxic effects on islet beta cells. ${ }^{17}$

In the present study, induction of rats with STZ led to a significant decrease in body weight in all administered groups when compared with the normal control (Table 1). However, a significant increase in body weight was seen in the tannin-treated diabetic rats when compared with the control at Week 3. Significant decrease in body weight was seen in the diabetic control groups, which continued until the end of the experimental period. The significant reduction in total body weight seen in the diabetic control rats despite their increased feed intake is attributed to the fact that STZinduced diabetes is characterised by severe loss of body weight, ${ }^{18}$ resulting from loss of fat from adipose tissue and catabolism of amino acids in muscle tissue. Moreover, there is loss or degeneration of structural proteins that are known to be a major contributor to body weight. Again, it is also an indication that the food being taken in is not being transformed into weight gain or growth attainment.

The findings from organ weight measurement in this study showed a significant increase in liver weight for the diabetic control rats and a non-significant change in the liver of diabetic tannin-treated rats when compared to the control liver (Table 2). The result also shows a non-significant change in the weight of the heart and kidney of treated and diabetic control rats. Moreover, a significant decrease was observed in the weight of the pancreas in the diabetic control rats when compared with the treated rats. The decrease in the weight of the pancreas could be attributed to the disruption and disappearance of pancreatic islets and selective destruction of insulin-producing cells. ${ }^{19,20}$ The significant increase in the weight of the liver seen in this study could be attributed to increased triglyceride accumulation leading to enlarged liver, which could be a result of the increased influx of fatty acids into the liver induced by hypoinsulinaemia. This finding is in agreement with previous work by Habibuddin et $\mathrm{al}^{21}$ Lee et $\mathrm{al}^{22}$ and Ohno et al. ${ }^{23}$

The destruction of the insulin-secreting $\beta$-cells starts 3 days post-STZ administration, reaching its peak at 3-4 weeks in rats, leaving less active cells, which results in a diabetic state. ${ }^{24,25}$ This explains the increased glucose concentration seen in the study on Day 3 after STZ administration (Table 3). Treatment with tannin extract from $S$. mombin leaves led to a significant decrease in blood glucose level on days 10 and 21; this decrease was comparable to that seen for the glibenclamide-treated 
groups but not comparable to the normal control. This result is in line with work conducted by Velayutham et al. ${ }^{26}$ on the antihyperglycaemic effect of tannins from Ficus racemosa. Moreover, Babby et al. ${ }^{27}$ showed that tannic acid reduces blood glucose levels in STZ-induced rats; Praveen et al. ${ }^{28}$ showed that tannins from Jatropha gossypifolia exert antihyperglycaemic effects. Studies have demonstrated that tannic acid induces glucose transport through activation of the insulin-mediated signalling pathway in adipocytes, in human diabetic patients. ${ }^{29}$ A study conducted by Xueqing et al. ${ }^{30}$ showed that tannic acid may have the potential to become the lead compound in the development of new types of antidiabetic pharmaceuticals that are able to reduce blood glucose levels without increasing adiposity.

Amylases are enzymes that hydrolyse the carbohydrates into small glucose particles. ${ }^{31}$ All the alpha amylase enzyme molecules act on alpha 1-4, 1-6 links of glucose residues. ${ }^{32}$ The enzyme alpha amylase is one of the most important in the human body, responsible for hydrolysis of starch into small sugar molecules. ${ }^{33}$ Amylase is one of the main enzymes produced in exocrine pancreatic cells and may be recognised as an adequate indicator of organ activity, both in physiological and pathological states. The significant decrease in serum amylase activity seen in the diabetic control rats could have resulted from the induction of the animals with STZ (Table 4). STZ has been proposed to cause a reduction in amylase activity by interfering with calcium and magnesium homeostasis and amylase gene expression. ${ }^{34}$ Administration of tannins extract to the diabetic rats led to a significant $(p<0.05)$ increase in serum amylase levels when compared to the diabetic control groups. This therefore shows that the tannins had a stimulant effect on this enzyme and probably exert a similar influence on other pancreatic hydrolases. It has been clearly demonstrated that a significant number of type I diabetes mellitus patients have impaired exocrine pancreatic function, as shown by a reduced duodenal output of enzymes in response to endogenous (meal, nutrients) and exogenous stimuli.

\section{Conclusion}

Tannin extract of S. mombin leaves has shown to be a potential agent in the treatment of hyperglycaemia resulting from diabetes as well as restoration of body weight and serum amylase level in STZ-induced diabetic rats.

\section{Acknowledgements Competing interests}

The authors declare that they have no financial or personal relationships which may have inappropriately influenced them in writing this article.

\section{Authors' contributions}

I.O. was the project supervisor, and was responsible for the experimental and project design and also made conceptual contributions. N.E. performed the experiments, prepared the samples and calculations and also prepared the write-up.

\section{References}

1. Dheer R, Bhatnagar P. A study of the antidiabetic activity of Barleria prionitis Linn Indian J Pharmacol. 2010;42:70-73. https://doi.org/10.4103/0253-7613.64493

2. Mohommadi J, Saadipour K, Delaviz H, Mohommadi B. Antidiabetic effects of an alcoholic extract of Juglans regia in an animal model. Turk J Med Sci. 2011;41:685-691.

3. Anoja PA, Kamani APW, Lakmini KBM. Study of antihyperglycaemic activity of medicinal plant extracts in alloxan induced diabetic rats. Anc Sci Life. 2013;32:193-198. https://doi.org/10.4103/0257-7941.131970

4. Anfenan MLK. Evaluation of nutritional and antidiabetic activity of different forms of ginger in rats. Middle-East J Scientific Res. 2014;21:56-62.

5. Mathers $C D$, Loncar D. Projections of global mortality and burden of disease from 2002 to 2030. PLoS Med. 2006;3(11):e442. https://doi.org/10.1371/journal. pmed.0030442

6. Shaw JE, Sicree RA, Zimmet PZ. Global estimates of the prevalence of diabetes for 2010 and 2030. Diabetes Res Clin Pract. 2010;87(1):4-14. https://doi. org/10.1016/j.diabres.2009.10.007

7. Boyle JP, Honeycutt AA, Narayan KM. Projection of diabetes burden through 2050: Impact of changing demography and disease in the US. Diabetes Care. 2001;24:1936-1940. https://doi.org/10.2337/diacare.24.11.1936

8. Ogbera AO, Adedokun A, Fasanmade OA, Ohwovoriole AE, Ajani M. The foot at risk in Nigerians with diabetis mellitus. The Nigerian scenario. Int J Endocrino Met. 2005;4:165-173.

9. Kanaujia A, Duggar R, Pannakal ST, et al. Insulinomimetic activity of two new gallotannins from the fruits of Capparis moonii. Bioorg Med Chem. 2010;18(11):3940-3945. https://doi.org/10.1016/j.bmc.2010.04.032

10. Muthusamy VS, Anand S, Sangeetha KN, Sujatha S, Arun B, Lakshmi BS. Tannins present in Cichoriumintybus enhance glucose uptake and inhibit adipogenesis in 3T3-L1 adipocytes through PTP1B inhibition. Chem Biol Interact. 2008;174(1):69-78. https://doi.org/10.1016/j.cbi.2008.04.016

11. Kunyanga CN, Imungi JK, Okoth M, Momanyi C, Biesalski HK, Vadivel V. Antioxidant and antidiabetic properties of condensed tannins in acetonic extract of selected raw and processed indigenous food ingredients from Kenya. J Food Sci. 2011;76(4):C560-C567. https://doi.org/10.1111/j.17503841.2011.02116.x

12. Pinent M, Blad M, Blad MC, Salvad MJ, Arola L, Ardevol A. Grape seed-derived procyanidins have an antihyperglycemic effect in streptozotocin-induced diabetic rats and insulinomimetic activity in insulin-sensitive cell lines. Endocrinology. 2004;145(11):4985-4990. https://doi.org/10.1210/en.2004-0764

13. Iwaela EJ, Oludare FD. Hypoglycemic effect, biochemical and histological changes of Spondias mombin Linn. and Parinari polyandra Benth. Seeds ethanolic extracts in alloxan-induced diabetic rats. J Pharmacol Toxicol. 2011;6:101-110. https://doi. org/10.3923/jpt.2011.101.112

14. Nkanu EE. Jeje SO, Ikpi DE, Gabriel OU. In vivo hypolipidemic and hypoglycemic effects of aqueous extract of Spondias mombin leaves and detoxification of reactive oxygen species in alloxan-induced diabetic rats. Int J Biol Chem Sci. 2016;10(4):1573-1579

15. Wallenfels K, Foldi P, Niermann H, Bender H, Linder D. The enzymatic synthesis, by transglucosylation of a homologous series of glycosidically substituted maltooligosaccharides and their use as mylase substrates. Carbohydr Res. 1978;61:359.

16. Amarowicz R, Piskuła M, Honke J, Rudnicka B, Troszyńska A, Kozłowska H. Extraction of phenolic compounds from lentil seeds (Lens culinaris) with various solvents. Pol J Food Nutr Sci. 1995;45:53-62.

17. Fadillioglu E, Kurcer Z, Parlakpinar H, Iraz M, Gursul C. Melatonin treatment against remote open injury induced by renal ischemia reperfusion injury in diabetes mellitus. Arch Pharm Res. 2008;31(6):705-712. https://doi.org/10.1007/ s12272-001-1216-3

18. Akbarzadeh A, Norouzian D, Mehrabi MR, et al. Induction of diabetes by streptozotocin in rats. Indian J Clinical Biochem. 2007;22(2):60-64. https://doi. org/10.1007/BF02913315

19. Heidari Z, Mahmoudzadeh-Sagheb H, Moudi BA. Quantitative study of sodium tungstate protective effect on pancreatic beta cells in streptozotocin-induced diabetic rats. Micron. 2008;39(8):1300-1305. https://doi.org/10.1016/j.micron. 2008.02.014

20. Kim JD, Kang SM, Seo BI, Choi HY, Choi HS, Ku SK. Anti-diabetic activity of SMK001, a poly herbal formula in streptozotocin-induced diabetic rats: Therapeutic study. Biol Pharm Bull. 2006;29(3):477-482. https://doi.org/10.1248/bpb.29.477

21. Habibuddin M, Daghriri HA, Humaira T, et al. Anti-diabetic effect of alcoholic extract of Caralluma sinaica $L$. on streptozotocin-induced diabetic rabbits. J Ethnopharmacol. 2008;117(2):215-220. https://doi.org/10.1016/j.jep.2008.01.021

22. Lee SI, Kim JS, Oh SH, Park KY, et al. Anti-hyperglycemic effect of Fomitopsis pinicola extracts in streptozotocin-induced diabetic rats. J Med Food. 2008;11(3):518-524. https://doi.org/10.1089/jmf.2007.0155

23. Ohno T, Horio F, Tanaka S, Terada M, Namikawa T, Kitch J. Fatty liver and hyperlipidemia in IDDM (insulin dependent diabetes mellitus) of Streptozotocin in treated shrews. Life Sci. 2000;66(2):125-131. https://doi.org/10.1016/S00243205(99)00570-6

24. Adeghate E, Ponery AS. GABA in the endocrine pancreas: Cellular localization and function in normal and diabetic rats. Tissue Cell. 2002;34:1-6. https://doi. org/10.1054/tice.2002.0217 
25. Kamtchouning P, Sokeng DS, Moundipa FP, et al. Protective role of Anacardium occidentale extract against streptozotocin induced diabetes rats. A Ethnopharmacol. 1998;62:55-99.

26. Velayutham R, Sankaradoss N, Ahamed KFH. Protective effect of tannins from Ficus racemosa in hypercholesterolemia and diabetes induced vascular tissue damage in rats. Asin Pacific J Trop Med. 2012:5:367-373. https://doi.org/10.1016/S19957645(12)60061-3

27. Babby A, Elanchezhiyan C, Suhasini S, Chandirasegaran G. Antihyperglycemic effect of tannic acid in streptozotocin induced diabetic rats. Int J Curr Res. 2014:6(3):5396-5398.

28. Praveen KI, Arun J, Chandrakumar SS, Sujatha S. Antihyperglycemic effect of tannic acid in streptozotocin induced diabetic rats. Eur J Biomed Pharm Sci. 2018;5(2):607-614.

29. Gin H, Rigalleau V, Caubet O, Masquelier J, Aubertin J. Effects of red wine, tannic acid, or ethanol on glucose tolerance in non-insulin-dependent diabetic patients and on starch digestibility in vitro. Metabolism. 1999;48:1179-1183. https://doi. org/10.1016/S0026-0495(99)90135-X
30. Xueqing L, Jae-kyung K, Yunsheng L, Jing L, Fang L, Xiaozhuo C. Tannic acid stimulates glucose transport and inhibits adipocyte differentiation in 3T3- I1 cells. J Nutr. 2005;135:165-171. https://doi.org/10.1093/jn/135.2.165

31. Windish WW, Mhatre NS. Microbial amylases. Adv Appl Microbiol 1965;7:273-304. https://doi.org/10.1016/S0065-2164(08)70389-7

32. Van Der Maarel MJEC, Van der Veen B, Uitdehaag JCM, Leemhuis $H$, Dijkhuizen L. Properties and applications of starch converting enzymes of the $\alpha$-amylase family. J Biotechnol. 2002;94:137-155. https://doi.org/10.1016/ S0168-1656(01)00407-2 33. Alexander R. Maltodextrins: Production, properties and applications. In: Schenk F,
Hebeda R, editors. Starch hydrolysis products: Worldwide technology, production and applications. New York: John Wiley and Sons Inc. ISBN-13: 9780471187967, 1992; p. 62-122.

34. Patel R, Yago MD, Victoria EM, Shervington A, Singh J. Mechanism of exocrine pancreatic insufficiency in streptozotocin-induced diabetes mellitus in rat: Effect of cholecystokinin-octapeptide. Mol Cell Biochem. 2004;261(1):83-89. https:// doi.org/10.1023/B:MCBI.0000028741.85353.c6 